\title{
Utilization and management of forest resources in Zaire
}

\author{
by P.D. Khasa ${ }^{1,2,3}$, G. Vallée ${ }^{4}$, J. Bélanger ${ }^{5}$ and J. Bousquet ${ }^{3}$
}

Tropical forest biomes are characterized by a high biodiversity. However, this biological complexity is diminishing rapidly. The causes for the decline and deterioration of tropical forests in Zaire were analysed. The main factors causing loss of biodiversity are shifting agriculture, fuelwood consumption, and fires in open forests and savannas. Measures for maintenance of forest biodiversity are proposed. These include in situ and ex situ conservation, suitable agricultural and silvicultural management systems, based on knowledge of genetic structure, genecology, reproductive biology of tropical plant populations, and biotic and edaphoclimatic factors. The active participation and support of the Zairean people as a whole, and policy and institutional reform are essential for a more effective utilization, management, and protection of the forests, so that socio-economic and environmental benefits are provided for present and future generations. Sustainable forestry development requires also a greater collaboration between government agencies and local communities and non-governmental organizations (NGOs).

Key words: Biodiversity, deforestation, national tropical forestry action plan, sustainable development, tropical forests, Zaire

\section{Introduction}

Zaire is in the central part of Africa and with a land area of 234.541 million ha $\left(2,345,410 \mathrm{~km}^{2}\right)$, is the third largest country of the continent. The forest biomes of Zaire (Fig. 1) are linked to its geographical location, geological, topographic, and climatic characteristics. These varied biomes support a rich flora and fauna. According to FAO (1981a,b) and the National Tropical Forestry Action Plan (Anon. 1990a), the closed forest area in Zaire is about 106 million ha and is concentrated in the central basin including some 10 million ha of riparian, swamp, and periodic swamp forests. In addition, there are some 72 million ha of open forests, 11 million ha of shrubland, 18 million ha of fallow forests, 0.1 million ha of bamboo forests, and 50,000 ha of mangrove. The total area of forest is, therefore, $88 \%$ of the total land surface of the country (Anon. 1990a).

Zaire's vast closed tropical forests represents about $50 \%$ of the African total forest cover (Mittermeier 1989). Taking into

\footnotetext{
${ }^{1}$ Department of Renewable Resources, University of Alberta, Edmonton, Alberta, Canada T6G 2H1 (Present address).

${ }^{2}$ Département de biologie, Faculté des sciences, B.P. 190, Université de Kinshasa, Zaire.

${ }^{3}$ Centre de recherche en biologie forestière, Faculté de foresterie et de géomatique, Université Laval, Québec, Canada G1K 7P4.

${ }^{4}$ Direction de la recherche, Ministère des ressources naturelles du Québec, 2700 rue Einstein, Ste-Foy, Québec, Canada G1P 3W8.

${ }^{5}$ Département du bois et de la forêt, Faculté de foresterie et de géomatique, Université Laval, Québec, Canada G1K 7P4.

Correspondence should be addressed to P.D. Khasa.
}

Les biomes forestiers tropicaux sont caractéristés par une biodiversité élevée. Cependant, cette richesse biologique est en train de diminuer rapidement. Les causes de la destruction des forêts tropicales au Zaïre ont été analysées. Les principaux facteurs causant la perte de la biodiversité sont l'agriculture itinérante sur brûlis, la récolte du bois en tant que source d'énergie et les feux des forêts claires et des savanes. Des mesures pour la conservation de la biodiversité forestière sont proposées. Celles-ci incluent la conservation in situ et ex situ, de systèmes adéquats d'aménagement agricole et sylvicole, basés sur la connaissance de la structure génétique, de la génécologie, de la biologie de reproduction des populations de plantes tropicales, des facteurs biotiques et edapho-climatiques. La participation active et le support de la population zaïroise tout entière et la réforme politique et institutionnelle sont essentielles pour une utilization, un aménagement et une protection plus efficaces des forêts, en vue d'assurer pour les générations présentes et futures des bénéfices socio-économiques et environementaux. Le développement durable de la foresterie exige aussi une grande collaboration entre les agences gouvernementales, les communautés locales et les organizations non-governmentales (NGOs).

Mots clés: Biodiversité, deforestation, plan national d'action forestier tropical, développement durable, forêts tropicales, Zaïre

account all categories of tropical forest biomes, Zaire is ranked second to Brazil (Anon. 1989). The most conspicuous feature of the closed forests is the high species diversity and low species density constituting the tree stratum $(20-55 \mathrm{~m})$. As many as 300 plant species may be counted in a single hectare, most of them belonging to different families (Vangu-Lutete 1981). On the other hand, closed forests of lower species diversity containing plant species representing only a few families are found such as the forests of Gilbertiodendron dewevrei and of Scorodophloeus zenkeri in Zaire (Vangu-Lutete 1981). The World Conservation Monitoring Centre (1992) reported, for Zaire, an estimate of 11,000 flowering plants (3,200 endemic species) and 7 gymnosperms, 415 species of mammals ( 25 endemic species), and 1,086 species of birds ( 23 endemic species), 33 endemic reptiles, and 53 endemic amphibians. Without compiling an exhaustive list, some of the animal species such as okapi (Okapia johnstoni), gorilla (Gorilla gorilla), white rhinoceros (Ceratotherium simum), black rhinoceros (Diceros bicornis), elephant (Loxondota africana), Nkuti (Cephalophus sylvicultor), and buffalo (Syncerus caffer) are now rare and endangered. Because the majority of tropical tree species are zoochorous, the decline of these animal species has led in the declining of many tropical tree species such as Treculia africana, T. brieyii, Canarium schweinfurthii, Irvingia robur, Klainedoxa gabonensis, Mammea africana, Pentadesma butyracea, Picralima nitida, Tetrapleura tetraptera, Tieghemella heckelii, Autranella congolensis, and Uapaca spp. (Pendje and Baya 1992).

Zaire is among the 12 megadiversity countries in the world. Together, these 12 countries hold up to $70 \%$ of the world's species diversity of vertebrates, swallowtail butterflies, and higher 


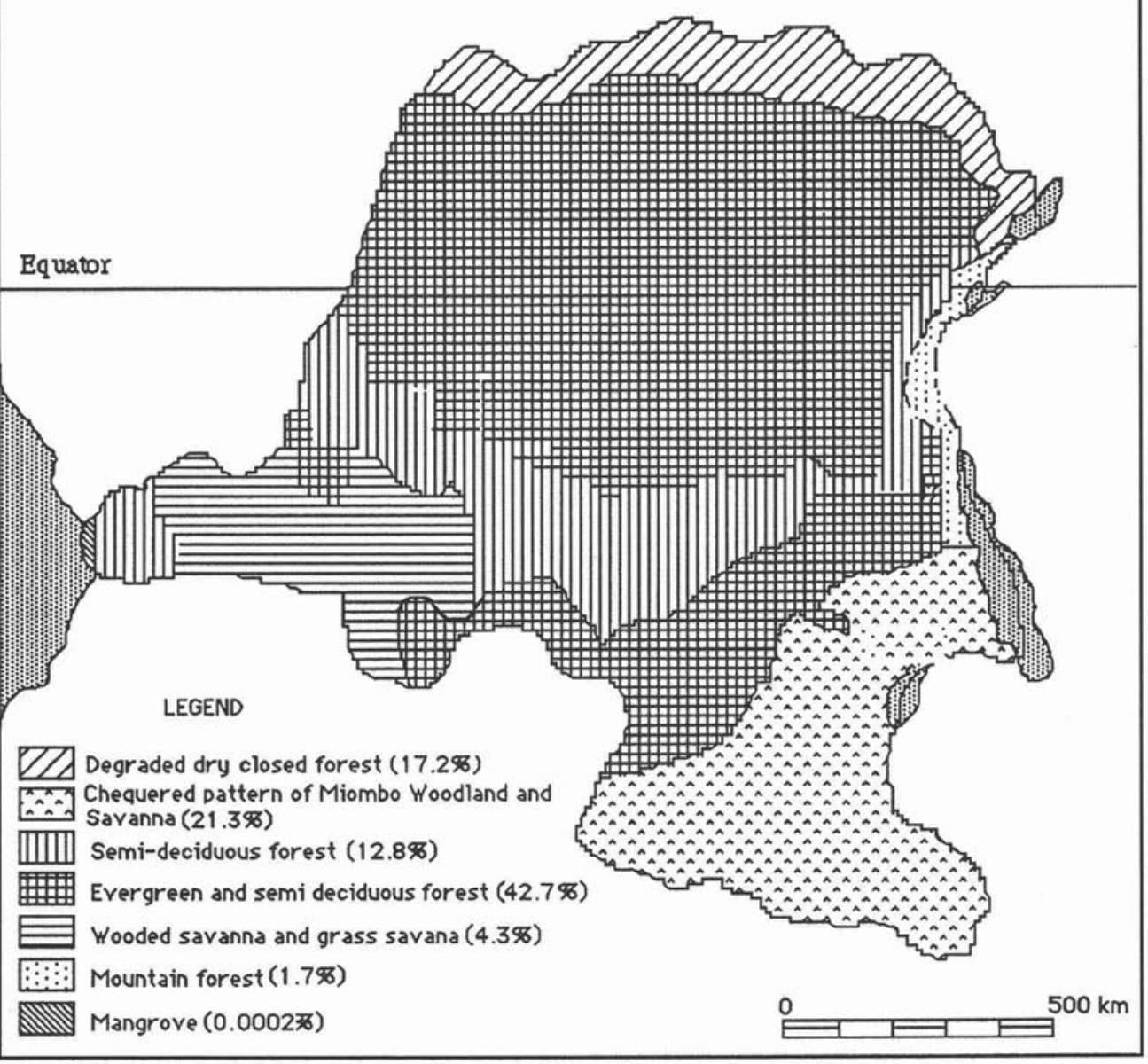

Figure 1. Distribution of forest biomes, including fallow forests and agroecosystems. The percentages in parentheses indicate the surface of each biome. Adapted from Anon. (1990a). plants (The World Conservation Monitoring Centre 1992). The forest resources in Zaire provide many goods and services including land for shifting agriculture, fuelwood, materials for rural construction and forestry industry, and other minor forest products. In addition, the ecotourism potential of zoological and botanical gardens, forest reserves, and parks is enormous. Therefore, the forests of Zaire are a central component of the economic and social structure of the country. This report is a diagnostic review of the main causes of destruction of forest resources in Zaire. In the light of this diagnosis, some strategies for the conservation of forest biodiversity are exposed.

\section{Causes of Forest Destruction}

In Zaire, Vangu-Lutete (1981) identified two major causes for the decline and deterioration of tropical forests: shifting agriculture (slash-and-burn agriculture) and fuelwood consumption. Some other causes could also be identified, such as fires in open forests and savannas, grazing, extraction for forest-based industries, and changes in land use associated with human settlement.

\section{Shifting and Modern Agriculture}

In the system of shifting agriculture, the forest is simply felled during the dry season and the debris is burned just before the next rainy season starts. Crops are then planted during the rainy season and the weeds are removed manually. To regenerate soil fertility, the fields are abandoned for a period of fallow. This system is well suited when periods of bush fallow are sufficiently long. However, the rapidly increasing population in Zaire (3\% per year) has reduced the periods of fallow to no longer than four years. This has led to changes in physical and chemical soil properties; and declining soil fertility and productivity. The majority of the soils belong to the oxisol order in central Zaire and ultisol order in eastern Zaire (Sanchez 1989). Because these soils are subject to leaching and drying once forest vegetation is removed, it is difficult to maintain their fertility. As reported by Kembola and Manyong (1989), three to four million small farmers practice so-called subsistencelevel agriculture on approximately six million ha. The main crops cultivated are cassava (Manihot esculenta), maize (Zea mays), rice (Oryza sativa), peanut (Arachis hypogaea), beans (Phaseolus spp.), and banana (Musa spp.) (Tables 1 and 2). Grasshoppers and rodents are the most important pests that cause serious damage to these crops. To the six million ha, subsistence farming results in an additional loss of forests of approximately 180,000 ha $\mathrm{yr}^{-1}$ (Anon. 1989).

Until 1970, about two million ha of forest land were converted to modern agriculture for the cultivation of industrial crops such as palm-oil (Elaeis guineensis), coffee (Coffea spp.), cacao (Theobroma cacao), tea (Camellia sinensis), rubber (Hevea 
Table 1. Allotment of farmers, forest area, total and cultivated areas in shifting and modern agriculture systems according to different administrative regions of Zaire $(1987)^{1}$

\begin{tabular}{|c|c|c|c|c|c|}
\hline \multirow[b]{2}{*}{ Agriculture systems } & \multirow{2}{*}{$\begin{array}{c}\text { Forest area } \\
(\text { ha })^{2}\end{array}$} & \multirow{2}{*}{$\begin{array}{l}\text { Number of } \\
\text { farmers }\end{array}$} & \multicolumn{3}{|c|}{ Area (ha) } \\
\hline & & & Total & Cultiv. & $\%$ \\
\hline \multicolumn{6}{|l|}{ Shifting agriculture } \\
\hline Bas-Zaire & $1,000,000$ & 198,442 & 244,811 & 244,811 & 100 \\
\hline Bandundu & $12,000,000$ & 330,977 & 520,935 & 520,935 & 100 \\
\hline Equateur & $42,000,000$ & 291,354 & 521,592 & 521,592 & 100 \\
\hline Haut-Zaire & $37,000,000$ & 456,674 & 506,778 & 506,778 & 100 \\
\hline Kivu & $18,000,000$ & 421,537 & 609,035 & 609,035 & 100 \\
\hline Kasaï-Occidental & $4,000,000$ & 273,290 & 495,720 & 495,720 & 100 \\
\hline Kasaï-Oriental & $10,000,000$ & 238,579 & 452,583 & 452,583 & 100 \\
\hline Shaba & $1,000,000$ & 325,763 & 470,462 & 470,462 & 100 \\
\hline Total & $125,000,000$ & $2,536,616$ & $3,821,916$ & $3,821,916$ & 100 \\
\hline \multicolumn{6}{|l|}{ Modern agriculture } \\
\hline Bas-Zaïre & ibid & 61 & 264,653 & 69,020 & 26 \\
\hline Bandundu & ibid & 83 & 120,534 & 28,016 & 23 \\
\hline Equateur & ibid & 151 & 377,678 & 140,378 & 37 \\
\hline Haute-Zaïre & ibid & 262 & 152,869 & 64,517 & 42 \\
\hline Kivu & ibid & 214 & 77,710 & 34,412 & 44 \\
\hline Kasaï-Occidental & ibid & 42 & 163,268 & 5,551 & 3 \\
\hline Kasaï-Oriental & ibid & 7 & 189,414 & 798 & 0.4 \\
\hline Shaba & ibid & 66 & 728,139 & 3,181 & 0.4 \\
\hline Total & ibid & 886 & $2,074,245$ & 345,873 & 17 \\
\hline
\end{tabular}

${ }^{1}$ Adapted from Kembola and Manyong (1989).

${ }^{2}$ The total forest area is 125 millions hectares, of which 106 millions in the central basin.

Table 2. Trends in cultivated surface, production and yield of both food and industrial crops in Zaire ${ }^{1}$ \begin{tabular}{lll}
\hline Culture & Cultivated surface & Total production
\end{tabular}

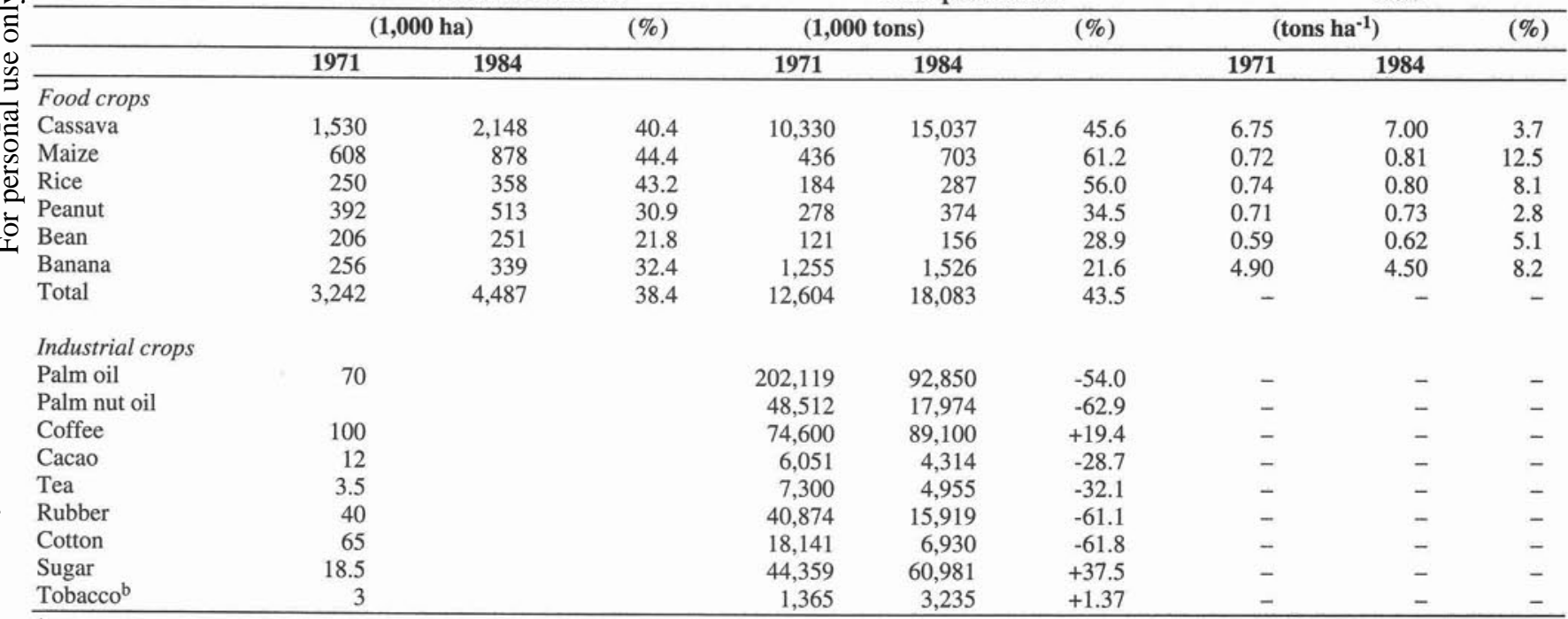

${ }^{1}$ Adapted from Kembola and Manyong (1989).

${ }^{2}$ Total production refers to 1978 and 1986 instead of 1971 and 1984 , respectively.

- data not available.

brasiliensis), cotton (Gossypium barbadense), sugar cane (Saccharum officinarum), and tobacco (Nicotiana tabacum) (Table 2 ). With the exception of coffee, sugar, and tobacco, the production of industrial crops is declining as a result of low investment in this sector (Kembola and Manyong 1989). Approximately 4.5 million ha are also devoted to grazing for cattle and other domestic animals (Kenbola and Manyong 1989). Livestock production, however, is less developed because of the prevalence of diseases, especially African trypanosomiases which are transmitted by tse-tse flies (Glossina spp.). Overall, the agricultural sector represents 15 to $20 \%$ of national gross profit and the income per habitant is 80 \$US yearly. Seventy to $80 \%$ of the labour nationwide is related to the agriculture sector which provides over $90 \%$ of the total domestic food supply (Kembola and Manyong 1989).

\section{Wood energy}

In spite of the great hydroelectric potential in Zaire, which is estimated at 774,000 gigawatts-hour $\mathrm{yr}^{-1}$, and other alternative energy sources, $87.7 \%$ of the total energy consumption (Table 3 ) is from ligneous origin of which $99 \%$ is for domestic uses (Zins and Kambale 1989). The total demand for wood energy 
Table 3. Energy consumption according to administrative regions of Zaire in $1987(\times 1,000 \text { TEP })^{1}$

\begin{tabular}{|c|c|c|c|c|c|c|}
\hline Region & Wood & Petroleum & Electricity & Coal & Total & $\%$ wood \\
\hline Kinshasa & 794 & 177 & 114 & - & 1,085 & 73.2 \\
\hline Bas-Zaïre & 581 & 85 & 27 & - & 693 & 83.8 \\
\hline Bandundu & 1,107 & 78 & - & - & 1,212 & 91.3 \\
\hline Haut-Zaïre & 1,258 & 56 & 6 & & 1,320 & 95.3 \\
\hline Kivu & 1,591 & 21 & 10 & - & 1,622 & 98.1 \\
\hline Shaba & 1,154 & 106 & 308 & 90 & 1,658 & 69.6 \\
\hline Kasaï-Oriental & 717 & 67 & - & - & 784 & 91.5 \\
\hline
\end{tabular}

${ }^{1}$ Compiled from Zins and Kambale (1989) in ton equivalent petroleum (TEP)

- data not available.

Table 4. Trends in wood energy demand from 1984 to 2005 in Zaire $^{1}$

\begin{tabular}{|c|c|c|c|c|c|c|}
\hline Uses & 1984 & 1990 & 1995 & 2000 & 2005 & $\begin{array}{c}\text { Annual growth } \\
\text { rate (\%) }\end{array}$ \\
\hline \multicolumn{7}{|l|}{$\begin{array}{l}\text { Firewood } \\
\text { (in } 1,000 \mathrm{~m}^{3} \text { ) }\end{array}$} \\
\hline Urban household & 4,649 & 6,594 & 8,619 & 11,264 & 14,722 & 5.64 \\
\hline Other uses & 111 & 118 & 123 & 129 & 137 & 1.00 \\
\hline Total & 22,809 & 25,449 & 27,241 & 28,817 & 29,819 & 1.28 \\
\hline Urban household & 7,321 & 10,387 & 13,574 & 17,741 & 23,188 & 5.64 \\
\hline Other uses & 100 & 106 & 112 & 117 & 123 & 1.00 \\
\hline Total & 7,421 & 10,493 & 13,686 & 17,858 & 23,311 & 5.60 \\
\hline \multicolumn{7}{|l|}{$\begin{array}{l}\text { Total } \\
\text { consumption }\end{array}$} \\
\hline
\end{tabular}

${ }^{1}$ Compiled from Zins and Kambale (1989) assuming neither energetic substitutes nor improved yield.

${ }^{2}$ Wood energy.

${ }^{3}$ Ton equivalent petroleum.

is estimated to increase from approximately 30 million $\mathrm{m}^{3}$ in 1984 to 53 million $\mathrm{m}^{3}$ in 2005 (Table 4). In this case, the annual increment demand in charcoal is $5.6 \%$ and $1.3 \%$ for firewood. The shortage in wood energy remains a serious problem in all the 14 official cities of Zaire. The actual need of charcoal alone is estimated to be 300,000 tons $\mathrm{yr}^{-1}$ in Kinshasa (capital of Zaire), and 600,000 tons $\mathrm{yr}^{-1}$ for the 14 official cities of Zaire (Zins and Kambale 1989). Estimating that $60 \mathrm{~m}^{3} \mathrm{ha}^{-1} \mathrm{yr}^{-1}$ is harvested for fuelwood and that $1 \mathrm{~m}^{3}$ of wood furnishes 0.075 tons of charcoal using traditional furnaces, the total area subjected to fuelwood production presently amounts to about 200,000 ha $\mathrm{yr}^{-1}$ to satisfy the needs of all cities. The problem is exacerbated by the population growth in cities, which reached an annual rate of $6 \%$ in 1990. For instance, Kinshasa had some six million people in 1993 (15\% of country population) and the demand for firewood and charcoal has resulted in the disappearance of forests within a $150 \mathrm{~km}$ radius around the city (Zins and Kambale 1989). In the villages, fuelwood is generally gathered on the same land prepared for the shifting agriculture.

\section{Fires in Open Forests and Savannas}

In Zaire, there are no accurate estimates of the area affected by fires each year, but an estimate would be in the order of $50 \%$ of the 105 million ha of savannas and open forests (Miombo). Fires are set to clean the vegetation for several rea- sons including hunting, cattle grazing, and shifting agriculture. During the dry season, the mosaic of Miombo and savannas is easily cleared with fire because the leaf litter becomes very dry and relative humidity is low. The evergreen forest is more resistent to fire because the leaf litter is constantly moist. The absence of vegetation due to fire contributes to soil erosion, destruction of the humus layer, and the destruction of fauna, and vegetation including woody biomass when fires are intense. Species that have bark resistant to fire tend to succeed in these conditions. Controlled burning, however, often improves the quality of the acidic soils by releasing nutrients rapidly, raising the alkalinity of the soil, reducing aluminum and/or manganese toxicity while increasing phosphorus availability to plants and checking pest populations (Okali 1992).

\section{Forest-based Industries}

Presently, SIFORZAL, a German private company and FORESCOM, a state company recently restructured with the financial support from the Canadian International Development Agency (CIDA) are the most important forest industries in the country. FORESCOM, renamed as SODEFOR, is now under the control of Portuguese interests. The other sawmills are characterized by low investment and obsolete machinery.

Since the colonial period, the Mayombe forest, situated near the coast in western Zaire, has been heavily exploited mainly for Limba (Terminalia superba), Iroko (Chlorophora excel- 
Figure 2. Closed forest areas (in million ha, right scale) and export of the main forest products (sawlogs+veneer logs) from central and western Africa (in million $\mathrm{m}^{3}$, left scale) during the period 1983-89. Compiled from FAO (1989), and Gerkens et al. (1991).

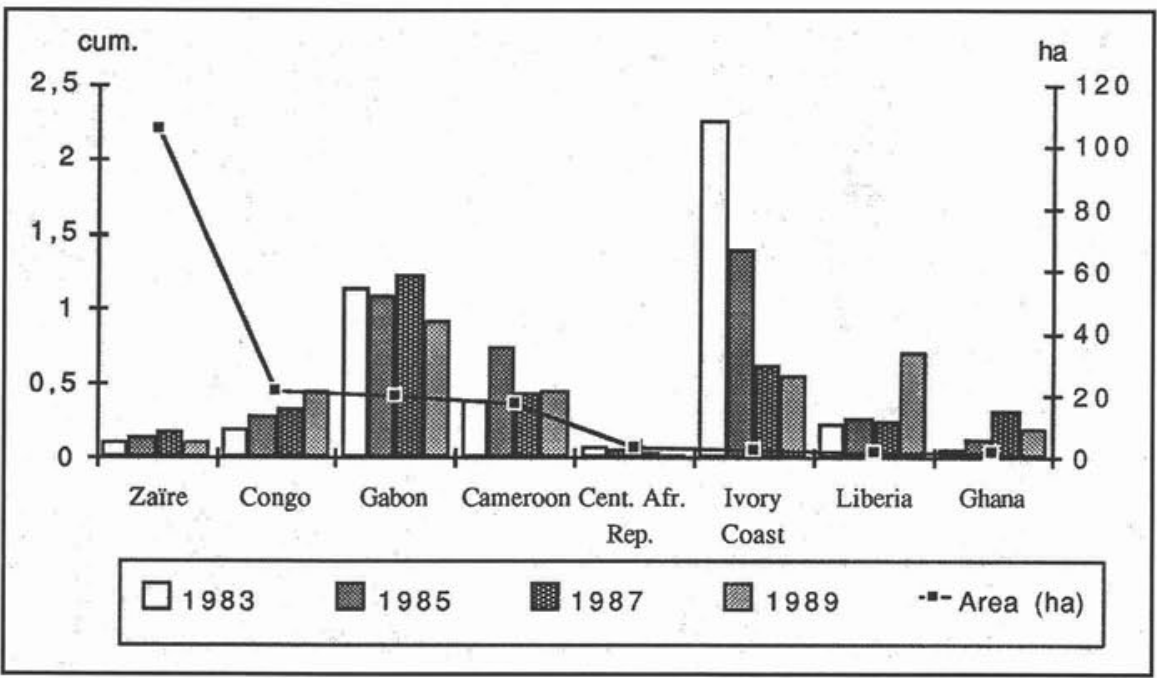

sa), Wenge (Millettia laurentii), Sapelli (Entandrophragma cylindricum) and African mahogany (Khaya anthotheca) due to relative ease for export of timber. A highly selective logging system is applied in Zaire. The very best trees are removed leaving only defective trees to provide the seed for the future generations. This approach is detrimental to the prudent management of biodiversity. Provenance and progeny tests have generally shown that slowly growing and defective trees resulting from dysgenic selection are genetically inferior (Zobel and Talbert 1984).

Although Zaire has the largest area of closed tropical forests in Africa, it is ranked seventh among the eight largest exporters of tropical forest products in central and western Africa (Fig. 2). Of the 21.5 million ha presently allocated to timber production (Pagezy and Ntoto 1989), about 100,000 ha yr$^{-1}$ are subject to forest industry exploitation. The annual allowable cut in Zaire is estimated to be 50 million $\mathrm{m}^{3}$ (Gerkens et al. 1991). However, annual average sawlog production is reported at 500,000 $\mathrm{m}^{3}$. In 1990 , rural pit sawing produced $525,000 \mathrm{~m}^{3}$ of sawnwood, whereas the annual sawnwood production from established industries averaged $132,000 \mathrm{~m}^{3}$ (Gerkens et al. 1991).

\section{Other Forms of Pressure on the Forest Ecosystems}

In Zaire, the forest is also a source of a diversity of non-timber products such as forage, fruits, oil producing seeds, honey, meat, fish, water, mushrooms, insects, larvae, fibres, cosmetics, rubber, gums, resins, waxes, tannins, and medicines for local pharmacopoeia as well as for the European pharmaceutical industry. Rauwolfia, Quinquina, and Pyrethrum are good examples of this latter point and some other species are now being used in traditional pharmacopoeia (Hirt and M'pia 1993). In 1986, export of rauwolfia products generated 23.5 million Z $(400,000$ $\$ \mathrm{US}$ ) and production of resins from some tropical trees (Copal) and fibers such as Punga (Urena lobata) attained 174 and 2,718 tons, respectively (Dr. Vangu-Lutete, per. com. 1991). In $1984,59,845$ tons of game meat and 39,696 tons of insects and larvae were harvested from the forest generating 2.7 billion $\mathrm{Z}$ (75.63 million \$US) (Kembola and Manyong 1989).

In summary, fuelwood gathering, shifting and sedentary agriculture practices, permanent pasture or grazing, bush fires, selective logging system, and hunting are considered to be the main causes of forest biodiversity decline in Zaire. Excluding bush fires, the total area affected by these main causes is presently about 16 million ha. To this must be added each year, a loss of some 180,000 ha of natural forests for slash-burn agriculture, 200,000 ha for fuelwood needs of the 14 official cities and 100,000 ha for forest-based industries.

\section{Conservation of Forest Biodiversity}

There is little scientific knowledge of the composition, structure and appropriate management practices for the heterogeneous tropical forests upon which to base a rational use incorporating the principle of sustained yield and assured regeneration for present and future generations (Anon. 1990b). There is also little knowledge about intraspecific variation, which is of vital importance for adaptation of species to variations in environmental conditions such as climate, soil, pests and disease through time, and to human interventions and domestication. Maintaining biodiversity is essential for productive agriculture and forestry (Pimentel et al. 1992). Some measures that can help maintain forest biodiversity and lead towards a more rational use of forests in Zaire are discussed below.

\section{Forest Inventory}

Forest inventory is the first step to be undertaken in any plan of conservation and management of forest resources. It provides the basic information on distribution of biomes, plant species composition and structure. The Service permanent d'inventaire et d'aménagement forestiers (SPIAF) of Zaire, established in early 1977 with the assistance of CIDA, is the agency currently involved in forest inventory as well as management operations. A survey of 16.7 million ha of forests was conducted, with 6.8 million ha in the Central Basin alone (Pagezy and Ntoto 1990). In addition, socio-economic data were also collected. To date however, the Mayombe area which is a heavily exploited forest is the only region under a management plan.

Forest inventories currently consider only the composition and the structure of the tree stratum. In future, an ecological inventory should be preferred as it considers the forest ecosystem as a product of abiotic and biotic factors interacting together (Matthews 1989). The ecological inventory is more efficient than the classical inventory in proposing integrated schemes of land management (Bélanger and Pineau 1987). Rapid inventory techniques using satellite imagery, aerial recon- 

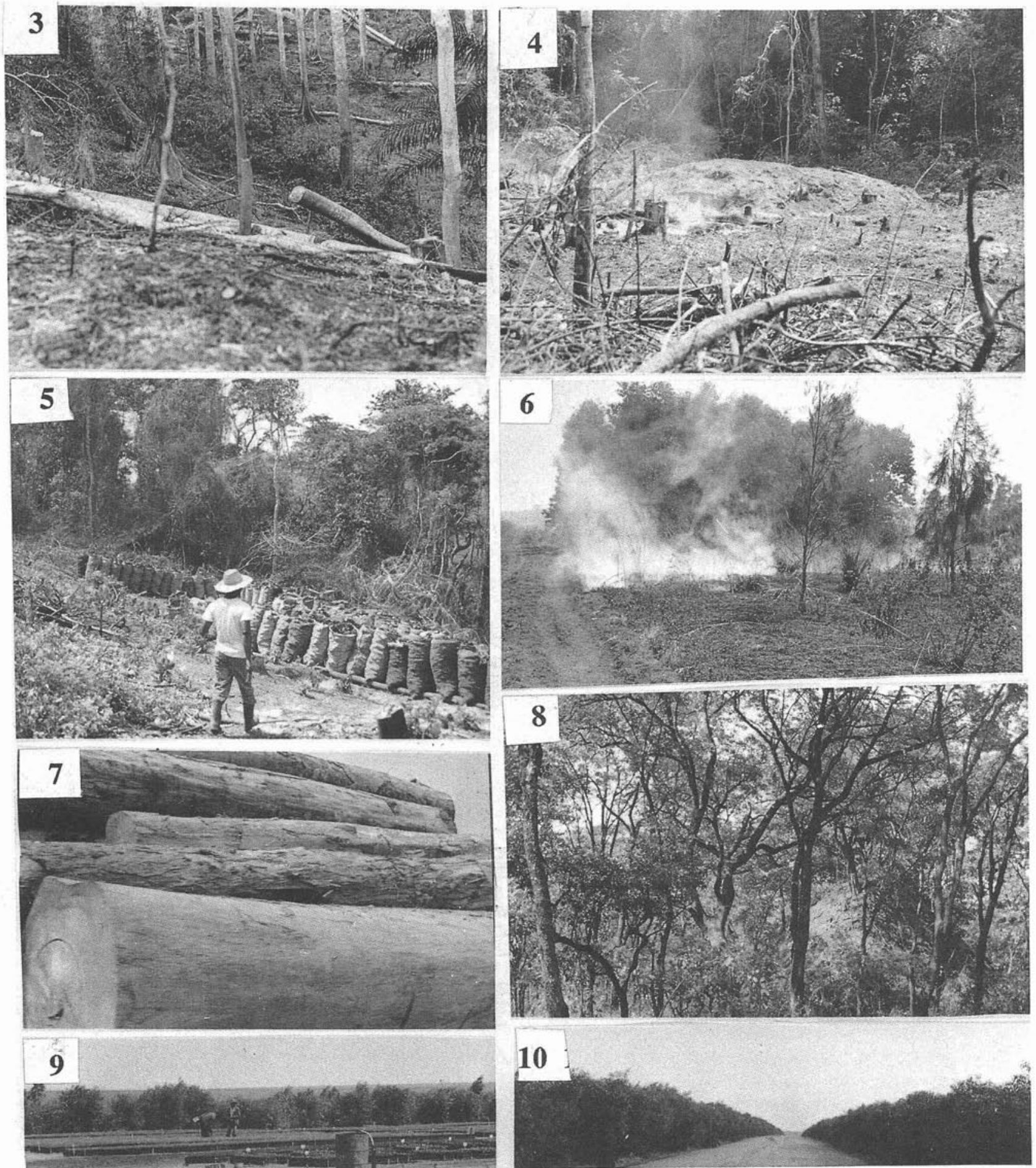

Figure 3. A secondary forest cut and burned down for the establishment of agroforestry systems using the intercropping of Musa spp. or Colocasia esculenta with Limba in the Mayombe region (Bas-Zaire). Behind, an old intercropping Limba-banana.

Figure 4-5. A closed forest cleared for charcoal production with Casamance's furnace in the Bandundu region.

Figure 6. Bush fire in the arboretum of Centre forestier de kinzono on the Bateke plateau (150 km N-E from Kinshasa).

Figure 7. Limba, an example of a threatened species, is the most heavily exploited commercial tree in the Mayombe region of Bas-Zaire.

Figure 8. A typical miombo forest, dominated by the association Brachystegia-Julbernardia-Isoberlinia and the presence of large ant-hills in the Shaba region.

Figure 9. Nursery of Racosperma auriculiforme in the Bateke plateau. This industrial tree planting on 8,000 ha is conducted by HVA-Holland Agro-industries bv, with financial support of the European economic community, in order to satisfy the needs of charcoal in Kinshasa.

Figure 10. Three-year old industrial tree plantation of Racosperma auriculiforme. The Hyparrhenia grass which formerly dominated this savannah has completely disappeared. 
naissance, field surveys, and geographical information system (GIS) to model variations in the spatial distribution of species richness and to predict where hot spots (geographic locations characterized by unusually high species richness, often of endemic species) occur, are now available and produce updated and accurate results in a matter of weeks rather than months or years (Heywood 1992; Stoms 1992; Stoms and Estes 1993).

\section{Management of Genetic Resources}

To achieve improved conservation and sustainable utilization, information is needed on ecological diversity as well as basic information on genetic diversity, spatial distribution of this diversity and, ideally, the underlying causes of the observed patterns of genetic diversity (Li et al. 1992). First, this information is essential in designing efficient conservation strategies to preserve genetic diversity, the ultimate source of adaptability for future generations. Second, this information is needed in using well adapted genotypes having desired traits of economic importance in artificial regeneration programs. Most characters of economic importance are generally under polygenic control and are also the result of both genetic and environmental factors. The study of genetic variation among and within poulations for these traits is accomplished by growing seedlings or clonal propagules in appropriate testing plantations (Zobel and Talbert 1984).

In the past, strategies have followed systematic schemes for sampling genetic resources. Presently, new technologies are used in population genetics to capture information on the genetic diversity in a species (among and within population variation), on its architecture and the mating system parameters, to certify pedigree materials, and to screen representative or unique genes, gene flow and introgression. The most commonly used and economical biochemical genetic markers are allozymes revealed by gel electrophoresis (Cheliak et al. 1987). Since the late 1960s, the application of electrophoresis to the measurement of genetic variation at enzyme loci has led to an explosion of studies in natural populations (Hamrick and Godt 1990). In the case of Zaire's forests, this technique appears economically suitable to assess the amount and geographic distribution of genetic diversity, to monitor the genetic erosion, and to estimate the mating system, especially for threatened and endangered species including those of economic and/or ecological importance in order to implement adequate measures of gene conservation.

Such studies have successfully been conducted in Zaire for two important exotic tree species, Racosperma auriculiforme (Cunn. ex Benth.) Pedley (Acacia auriculiformis) and Racosperma mangium (Willd.) Pedley, comb. nov. (Acacia mangium) (Khasa et al. 1993, 1994a), and for one native commercial tree species, Terminalia superba (Vignernon 1984). In addition, information about flowering, seed set, fruit dispersal, seed germination, seedling mortality and replacement is important in regeneration practices (Hamrick and Loveless 1989). Indeed, a recent ecological study conducted in Zaire, has shown a strong interdependance between plant and animal species to maintain tropical forest biodiversity for present and future generations (Pendje and Baya 1992). More recently, DNA fingerprinting methods using restriction fragment length polymorphism (RFLP) or the random amplified polymorphic DNA (RAPD) markers were developed for detecting DNA polymorphism between populations or species and for quantitative trait loci (QTL) mapping (Tuskan 1992;
Ragot and Hoisington 1993). However, application of these techniques to tropical tree species requires cooperation with industrialized nations.

\section{Recommendations for Conservation of Biodiversity In situ and ex situ conservation}

The goal of gene conservation is to preserve a representative sample of the total existing diversity (Marshall 1990). As outlined by Li et al. (1992), conservation of biodiversity could proceed at three levels: 1 ) the diverse landscapes and ecosystems are conserved to preserve diversity of organisms and processes operating at these higher levels of organization, 2) conservation of the species diversity within ecosystems, especially rare and endangered species, and 3) conservation of the genetic diversity within species (gene conservation).

Biodiversity conservation could be achieved by in situ conservation through preserving populations of species in the environment in which they evolved. According to Pagezy and Ntoto (1990), the allocated surface of Zaire's forests free of, or having limited intervention of human activity, includes national parks ( 8 million ha), fauna, hunting, and natural reserves (13 million ha), and classified forests and forest reserves $(753,000 \mathrm{ha})$. The total area represents $9 \%$ of Zaire's land. Basic information related to genetic diversity of Zaire's forest resources is still lacking. Therefore, the optimum strategy should be to preserve many individuals from as many sites, and to cover as broad a range of environments as possible (Marshall 1990). For widespread species, a few large populations in different geographic areas would be a minimum requirement for effective in situ conservation (Moran and Hopper 1987). But it is extremely difficult to implement in situ conservation of forest resources in Zaire because of the extreme population pressures on these areas of reserves.

Biodiversity conservation could also be achieved by $e x$ situ (out of the natural position) conservation through preserving populations and individuals in genetic test plantations, arboreta, collections in botanical gardens, or seed banks, and captive breeding programs in zoological gardens. At the present moment, collections in zoological and botanical gardens represent only about 3,000 ha (Pagezy and Ntoto 1990). For species, or segments of a species gene pool, that are endangered or threatened, ex situ conservation is needed for each population at each site. In Zaire, examples of tree species threatened by overexploitation for trade purposes are Terminalia superba, Chlorophora excelsa, Millettia laurentii, Entandrophragma cylindricum, Khaya anthotheca, Pericopsis elata (Anon. 1988). The future of other tree species that are dependant on seed dispersal by animals and birds that are rare or endangered is also in question (Pendje and Baya 1992). Unfortunately, there is no gene bank facility in the country for the ex situ storage of seed, pollen, grafts, cuttings or in vitro lines. Methods of vegetative propagation by cuttings or grafts have been developed for Terminalia and Eucalyptus (Martin and Quillet 1974; Boutin 1990) and for Racosperma spp. (Khasa et al. 1995). To render ex situ preservation fully efficient, concurrent monitoring and evaluation of materials and genotypes in plantations should also be encouraged (Wilkes 1989).

Ledig (1988) discussed the advantages and disadvantages of ex situ and in situ techniques and presented the in situ reserves as often less costly. Consequently, the intensification of in situ conservation involving participation of the whole 
population should be encouraged in Zaire (Von Richter 1991). Presently, over $85 \%$ of the seeds or vegetative propagules for food production are conserved either in appropriate jars for the short term, or in field genebanks by local farmers themselves. Efforts should be focused on the maintenance of genetic diversity for endangered species. For most species that are not under immediate threat but that cannot survive in the long term unless protected, a balance between ex situ and in situ conservation would be appropriate (Marshall 1990). We need to stress an often neglected point; that is, the use and conservation of genetic resources must be dynamic processes, since resistance to pests, evolution of pathogens, hosts, and other biotic factors cannot be captured in a fixed state (Namkoong 1991).

For the conservation of most orthodox seeded crops, ex situ conservation in low-technology seed banks would be more affordable. There are, however, numerous important tropical species whose seed is recalcitrant and for which research is needed to define the mechanisms of desiccation and chilling injury. Some methods of alleviating seed recalcitrance such as cryogenic treatments involving cryoprotectants or the use of excised embryos are now being investigated (Towill and Roos 1989; Chin 1990). Ex situ cryopreservation of embryogenic calli in which genetic and organogenic qualities remain intact would require co-operative endeavours between institutions in developing and industrialized countries (Ledig 1989; Franclet 1989).

\section{Sustainable Agriculture and Forestry}

Various measures have been proposed to restore and sustain supplies outside national parks and reserves. Improvement of shifting agriculture through more ecological and more sustainable agricultural systems, especially agroforestry is one of the most promising measures. Due to the integration of their production activities on the same piece of land, these systems may create buffer zones surrounding natural forests and help to preserve them. For example, promising results have been obtained in Zaire by using Leucaena leucocephala in alley cropping with maize or as a green manure and in the intercropping of Cassava with $R$. auriculiforme or Terminalia superba with banana, coffee, cacao or taro (Malele 1991; Khasa et al. 1994b). The maintenance of small livestock at the village level such as rabbits, goats, sheeps and pigs or domestication of some overhunted wild species such as Cephalophus spp., Tryonomys swinderianus, Cricetomys emini, Atherurus africanus, and Potamochoerus porcus, can better be integrated into agro-forestry systems and rural development. It is also important to control man-made fires, as well as other potentially destructive activities such as poaching, hunting, cattle ranching and pit sawing. To seek new alternatives to slash-and-burn agriculture and to conservation of forest biodiversity, the role of local chiefs and non-governmental organizations (NGOs), and of political decision-makers and others is essential through profitable projects.

Due to Zaire's high forest potential, the government has fixed wood production to six million $\mathrm{m}^{3}$ in year 2000 without impairing the forest capital, assuming adequate regeneration with seeds from the in situ populations, enrichment planting, vigorous plantation programs and implementation of agro-forestry systems. However, the Mayombe forest has been subjected to intensive and continuing exploitation for the last 80 years, and presently shows a deficit in timber supply. Therefore, forest operations should be reduced to a level lower than the allowable cut and at the same time, forest management should be initiated. The concept of Genetic Resource Management Unit (GRMU) or managed forests (Ledig 1988) may provide a mechanism for conserving genetic resources and simultaneously providing sustainable economic benefits.

In Zaire, over 700 tree species have been inventoried, of which about only 34 are presently subjected to intensive exploitation for trade (Anon. 1988). Considering its authority, the Centre de promotion du bois (CPB) has to promote the so-called secondary or commercially less known species and consequently new wood technologies and waste utilization should be developed. Also, the Direction de la gestion des ressources naturelles renouvelables (DGRNR), acting as the management and control authority, should meet the challenges and exercise proper controls. From 1986 to 1990, CIDA's assistance has been provided to this institution through the project Appui à la gestion forestière (AGEF).

\section{Domestic Wood Energy Substitutes}

Fuelwood gathering is considered to be the most important cause of forest destruction in Zaire. Increasing reforestation activities throughout the country, particularly with appropriate agroforestry systems, using fast-growing trees will reduce pressures on natural forests. Plantations and woodlots with fastgrowing trees such as $R$. auriculiforme and $R$. mangium required to satisfy the demand for fuelwood and other rural needs are now being managed in Zaire (Khasa et al. 1994b). On the other hand, where successful, measures to promote alternative energy substitutes will reduce the harvesting pressure on ligneous material in the forests for fuelwood. Alternate energy sources such as hydroelectricity, solar energy, and methane are possible in Zaire, but would require large investments to establish the required infrastructure. Therefore, fuelwood will remain the main source of energy for the majority of people in the foreseeable future. Smoke from wood fires used for cooking contain toxic and harmful substances that are potentially carcinogenic. The Centre d'adaptation des techniques de l'énergie-bois (CATEB) was born in 1983 with CIDA's financial support and its goal is to promote more efficient cooking stoves and improved methods of charcoal production. Biogas production, as an alternative technology, could also be applicable in some areas where organic manure is abundant.

\section{Training and Research}

Maintaining forest biodiversity requires well trained manpower and the participation of the whole population. While Zaire has the largest forest areas in Africa, it is surprising that there is no forestry school at the university level. From 1971 to 1973 , CIDA supported a department of forestry at the University of Kinshasa. This department was moved to Yangambi at the end of 1973 and teaching was put into abeyance in 1979. Since then, the training program of about five Zairian forest engineers per year was pursued at Laval University in Québec till 1993, whereas 20 to 25 graduate forest engineers would be needed annually in the country. About 20 forest technicians graduate every year from the Institut supérieur d'enseignement agronomique (ISEA) in Bengamisa. Therefore, the re-establishment of a forestry faculty in Zaire should be on today's agenda in order to train more qualified foresters.

Since 1974, the Institut national pour la recherche agronomique (INERA), the former Institut national pour l'étude agronomique 
au Congo (INEAC), has focused its research priorities only on food and industrial crops because of its financial limitations. Recently, a restructure of the research programs included some forest aspects (Anon. 1991). However, an independent institution entirely devoted to forest research would better address the multiple problems related to a proper integrated management of Zaire's forests.

\section{Conclusion}

Because of the world's fast-diminishing rain forests, an international coordinated effort called "The Tropical Forestry Action Plan" was born in 1985 in order to save the world's remaining tropical rain forests (FAO 1985). Recently, an Earth Summit was held in Rio de Janeiro, Brazil, from 3-14 June 1992 which agreed on a global plan for sustainable development, known now as Agenda 21. With the help of CIDA, Zaire now has a formal proposal, the so-called National Tropical Forestry Action Plan (NTFAP); it is the cornerstone for utilizing, managing and protecting Zaire's forests based on the principle of sustainable development (Anon. 1990b). The proposal outlines the strategies needed for sustainable development by focusing on five areas: 1) forestry in land use, 2) forest-based industrial development, 3) fuelwood and energy, 4) conservation of tropical forest ecosystems, 5) forest institutions. However, there has been no action taken to date on this plan due to a lack of political, financial, and institutional support. The implementation of this plan in conjunction with the integrated strategies discussed above on conservation of forest biodiversity would lead to a more rational and sustained use of Zaire's forest resources.

We must emphasize that the conservation of forest biodiversity is a public task and must be integrated with other land-use practices based on sustainable development. Therefore, the proposed solutions may lead to fruitful results only if there is active participation of the whole population, particularly the women (because of their fundamental role in shifting agriculture and fuelwood gathering). In view of the current lack of political leadership, the role of NGOs will be crucial. A good measure of coordinated effort by Zaireans will have an important impact if financial support through international agencies is provided.

\section{Acknowledgements}

This work was supported by a grant from the Canadian International Development Agency (CIDA) to P.D. Khasa. We are grateful to Dr. C. Opio (Forestry Program, University of Northern British Columbia), Drs M. Grandtner, P. Li, and K. Kambale (Département du bois et de la forêt, Université Laval), and Dr. D. Rousseau (FAO, Rome) for their valuable comments on previous drafts of this manuscript. We also thank Dr. Vangu-Lutete, the former coordinator of the National Tropical Forestry Action Plan in Zaire, for access to some original data and documents valuable in making this review.

\section{References}

Anon. 1988. Liste des essences forestières du Zärre. Service permanent d'inventaire et d'aménagement forestiers. 1 ère éd., Ministère de l'environnement et conservation de la nature du Zaïre, Kinshasa.

Anon. 1989. Mémento du forestier. Centre technique forestier tropical. 3ème éd., Ministère de la coopération et du développement de la France, Paris. pp. 1-56.

Anon. 1990a. Plan d'action forestier tropical (PAFT). Ministère de l'environnement et conservation de la nature du Zaïre, Kinshasa.

Anon. 1990b. Sustainable development and forest management.
National Forum Proceedings, Canadian council of forest Ministers of Canada, Halifax.

Anon. 1991. Plan directeur de la recherche agronomique au Zaïre. Ministère de l'enseignement supérieur universitaire et de la recherche scientifique du Zaïre, Kinshasa.

Bélanger, L. and M. Pineau. 1987. La classification taxonomique des stations forestières: un cadre de référence au suivi et à la prévision des effets de l'action sylvicole. Pp. 816-834 In: B. Sadler (ed.). Audit and evaluation in environmental assessment and management, Canadian and International Experience, Vol. 2. Environment Canada, the Banff Centre, Canada.

Boutin, B. 1990. Greffage en fente terminale herbacée du Terminalia superba Engler et Diels. Bois et Forêts des Tropiques 225: 33-41.

Cheliak, W.M., F.C.H. Yeh and J.A. Pitel. 1987. Use of electrophoresis in tree improvement programs. For. Chron. 63: 89-96. Chin, H.F. 1990. Storage of recalcitrant seeds: past, present and future. Pp. 89-92 In: J.W. Turnbull, (ed.). Tropical tree seed research. Proceedings of an international workshop, ACIAR Proceedings No 28. Gympie, Qld., Australia, 21-24 August 1989.

FAO. 1981a. Projet d'évaluation des ressources forestières tropicales (dans le cadre du GEMS): les ressources forestières de l'Afrique tropicale. Première partie: synthèse régionale. FAO, Rome.

FAO. 1981b. Projet d'évaluation des ressources forestières tropicales (dans le cadre du système mondial de surveillance continue de l'ennironnment): les ressources forestières de l'Afrique tropicale. Deuxième partie: résumé par pays. FAO, Rome. pp. 551-575.

FAO. 1985. Tropical forestry action plan. FAO, Rome.

FAO. 1989. Yearbook of forest products. FAO, Rome.

Franclet, A. 1989. Biotechnology and the genetic improvement of trees. Pp. 263-278 In: A. Sasson and V. Costarini (eds.). Plant biotechnologies for developing countries. Proceedings of an international symposium organized jointly by the CTA and FAO and held in Luxembourg, 26-30 June 1989.

Gerkens, M., J. Schwettmann and M. Kambale 1991. Le secteur de l'exploitation forestière artisanale au Zaïre et son avenir. Rapport final de l'étude sur les petits exploitants forestiers. Ministère de l'environnement et conservation de la nature du Zaïre, Kinshasa. Hamrick, J.L. and M.J. Godt. 1990. Allozyme diversity in plant species. Pp. 43-63 In: A.H.D. Brown, M.T. Clegg, A.L. Kahler and B.S. Weir (eds.). Plant population genetics, breeding, and genetic resources. Sinauer, Sunderland, Mass.

Hamrick, J.L. and M.D. Loveless. 1989. The genetic structure of tropical tree populations: associations with reproductive biology. Pp. 129-146 In: J.H. Block and Y.B. Linhart (eds.). The evolutionary ecology of plants. Westview Press, Boulder, San Francisco, and London.

Heywood, V.H. 1992. Efforts to conserve tropical plants - a global perspective. Pp. 1-13 In: R.P. Adams and J.E. Adams (eds.). Conservation of plant genes: DNA banking and in vitro biotechnology. Plant Biotechnology Center, Baylor University, Waco, Texas. Academic Press, Inc., San Diego, California.

Hirt, H.M. and M'pia, B. 1993. La médecine naturelle en Afrique: comment se soigner par les plantes tropicales. Centre de vulgarisation agricole, Kinshasa.

Kembola, K. and M. Manyong. 1989. Éude sur la foresterie et l'utilisation des terres. PAFT. Ministère de l'environnement et conservation de la nature du Zaïre, Kinshasa.

Khasa, P.D., W.M. Cheliak and J. Bousquet. 1993. Mating system of Racosperma auriculiforme in a seed production area in Zaïre. Can. J. Bot. 71: 779-785.

Khasa, P.D., W.M. Cheliak and J. Bousquet. 1994a. Genetic variation in 26 populations of Racosperma auriculiforme and $R$. mangium using allozymes. Can. J. For. Res. 24: 1123-1132.

Khasa, P.D., G. Vallée and J. Bousquet. 1994b. Biological considerations in the utilization of Racosperma auriculiforme and R. mangium in tropical countries with emphasis on Zaire. J. Trop. For. Sci. 6: 422443. 
Khasa, P.D., G. Vallée and J. Bousquet. 1995. Provenance variation in rooting ability of juvenile stem cuttings from Racosperma auriculiforme and $R$. mangium. For. Sci. 41: 305-320.

Ledig, F.T. 1988. The conservation of diversity in forest trees: why and how should genes be conserved? Bioscience 38: 471-479.

Ledig, F.T. 1989. The relevance of biotechnology to forestry in developing countries. Pp. 255-261 In: A. Sasson and V. Costarini (eds.). Plant biotechnologies for developing countries. Proceedings of an international symposium organized jointly by the CTA and FAO and held in Luxembourg, 26-30 June 1989.

Li, P., J. Mackay and J. Bousquet. 1992. Genetic diversity in Canadian hardwoods: implications for conservation. For. Chron. 68: 709-719.

Malele, M. 1991. Contribution à la remise en valeur des terres dégradées de la zone périurbaine de Kinshasa par un système agroforestier. Thèse de maîtrise, Faculté de foresterie et de géomatique. Université Laval, PQ.

Martin, B. and G. Quillet. 1974. Bouturage des arbres forestiers au Congo: résultats des essais effectués à Pointe-Noire de 1969 à 1973. Bois et Forêts des Tropiques 154: 41-57, 155: 15-33, 156: 39-61, 157: 21-39.

Marshall, D.R. 1990. Crop genetic resources: current and emerging issues. pp. 367-388 In: A.H.D. Brown, M.T. Clegg, A.L. Kahler and B.S. Weir (eds.). Plant population genetics, breeding, and genetic resources. Sinauer, Sunderland, MA.

Matthews, J.D. 1989. Silviculture systems. Clarendon Press, Oxford. Mittermeier, R.A. 1989. Primate diversity and the tropical forest: case studies from Brazil and Madagascar and the importance of the megadiversity countries. Pp. 145-154 In: E.O. Wilson and F.M. Peter (eds.). Biodiversity. National Academy Press, Washington, DC.

Moran, G.F. and D. Hopper. 1987. Conservation of genetic resources of rare and widespread eucalypts in remnant vegetation. Pp. 151-162 In: D.A. Saunders, G.W. Arnold, A.A. Burbidge and A.J.M. Hopkins (eds.). Nature conservation: the role of remnants of native vegetation. Surrey Beatty, and Sons Pty, Chipping Norton, N.S.W., Australia. Myers, N. 1989. Tropical forests and their species going, going? Pp. 28-35 In: E.O. Wilson and F.M. Peter (eds.). Biodiversity. National Academy Press, Washington, DC.

Namkoong, G. 1991. Maintaining genetic diversity in breeding for resistance in forest trees. Ann. Rev. Phytopathol. 29: 325-342.

Okali, D.U.U. 1992. Sustainable use of west Africa moist forest lands. Biotropica 24: 335-344.

Pagezy, P. and N. Ntoto. 1990. Aménagement du territoire. PAFT, Ministère de l'environnement et conservation de la nature du Zaïre, Kinshasa.

Pendje, G. and M. Baya. 1992. La réserve de biosphère de Luki (Mayombe, Zaïre): patrimoine floristique et faunique en péril.
UNESCO, Paris.

Pimentel, D., U. Stachow, D.A. Takacs, H.W. Brubaker, A.R. Dumas, J.J. Meaney, J.A.S. O'Neil, D.E. Onsi and D.B. Corzilius. 1992. Conserving biological diversity in agricultural/forestry systems. BioScience 42: 354-362.

Ragot, M. and D.A. Hoisington 1993. Molecular markers for plant breeding: comparisons of RFLP and RAPD genotyping costs. Theor. Appl. Genet. 86: 975-984.

Sanchez, P.A. 1989. Soils. Pp. 73-88 In: H. Lieth and M.J.A. Werger (eds.). Ecosystems of the world 14B: tropical rain forest ecosystems. Elsevier Scientific publishing company, Amsterdam, The Netherlands. Stoms, D.M. 1992. Effects of habitat map generalization in biodiversity assessment. Photogrammetric Engineering and Remote Sensing 58: 1587-1591.

Stoms, D.M. and J.E. Estes. 1993. A remote sensing research agenda for mapping and monitoring biodiversity. International Journal of Remote Sensing 14: 1839-1860.

Towill, L.E. and E.E. Roos. 1989. Techniques for preserving of plant germplasm. Pp. 379-403 In: L. Knutson and A.K. Stoner (eds.). Biotic diversity and germplasm preservation, global imperatives. Kluwer Academic Publishers, The Netherlands.

Tuskan, G.A. (ed.). 1992. Marker-aided selection: a tool for the improvement of forest tree species. Can. J. For. Res. 22: 998-1061.

Vangu-Lutete, L.M. 1981. Elargissement des perspectives d'aménagement forestier dans les tropiques humides. Cas du Zaïre. Thèse de Ph.D. Faculté de foresterie et de géomatique, Université Laval, PQ. Vigneron, P. 1984. Variabilité génétique des provenances ivoriennes et congolaises de Terminalia superba ENGLER et DIELS: apports de polymorphisme enzymatique. Thèse de doctorat, Université de ParisSud, Paris.

Von Richter, W. 1991. Problems and limitations of nature conservation in developing countries: a case study in Zaire. Pp. 185-197 In: W. Erdelen, N. Ishwaran and P. Müller (eds.). Tropical ecosystems. Proceedings of the international and interdisciplinary symposium. Saarbrücken, Germany, 15-18 June 1989.

Wilkes, G. 1989. Germplasm preservation: objectives and needs. Pp. 13-41 In: L. Knutson and A.K. Stoner (eds). Biotic diversity and germplasm preservation, global imperatives. Kluwer Academic Publishers, The Netherlands.

World Conservation Monitoring Centre. 1992. Global biodiversity: status of the earth's living resources. Chapman and Hall, London, U.K.

Zins, R. and K. Kambale. 1989. L'énergie-bois au Zaïre, Bilan et perspectives. PAFT, Agence canadienne de développement international, Hull, Canada.

Zobel, B. and J. Talbert. 1984. Applied forest tree improvement. John Wiley, and Sons, New York, NY. 